\title{
Elemental Analysis of Phytotherapeutic Products by Inductively Coupled Plasma-Tandem Mass Spectrometry
}

\author{
Alex Virgilio, Renata Stabile Amais, Daniela Schiavo, José Anchieta Gomes \\ Neto \& Joaquim de Araújo Nóbrega
}

To cite this article: Alex Virgilio, Renata Stabile Amais, Daniela Schiavo, José Anchieta Gomes Neto \& Joaquim de Araújo Nóbrega (2017) Elemental Analysis of Phytotherapeutic Products by Inductively Coupled Plasma-Tandem Mass Spectrometry, Analytical Letters, 50:5, 842-852, DOI: 10.1080/00032719.2016.1195839

To link to this article: https://doi.org/10.1080/00032719.2016.1195839

Џ Article views: 85

View Crossmark data ¿ 


\title{
Elemental Analysis of Phytotherapeutic Products by Inductively Coupled Plasma-Tandem Mass Spectrometry
}

\author{
Alex Virgilio a, Renata Stabile Amais ${ }^{b}$, Daniela Schiavoc, José Anchieta Gomes Neto ${ }^{d}$, and \\ Joaquim de Araújo Nóbrega ${ }^{a}$ \\ aGroup for Applied Instrumental Analysis, Department of Chemistry, Federal University of São Carlos, \\ São Carlos, São Paulo, Brazil; ' $C e n t e r$ for Nuclear Energy in Agriculture, University of São Paulo, Piracicaba, \\ São Paulo, Brazil; 'Agilent Technologies Brazil, Barueri, São Paulo, Brazil; dDepartment of Analytical Chemistry, \\ Institute of Chemistry, São Paulo State University - UNESP, Araraquara, São Paulo, Brazil
}

\begin{abstract}
A procedure for the determination of $\mathrm{As}, \mathrm{Cd}, \mathrm{Cr}, \mathrm{Ni}, \mathrm{Pb}$, and $\mathrm{V}$ in phytotherapy medicines by inductively coupled plasma-tandem mass spectrometry is reported. The use of tandem mass spectrometry with oxygen into an octopole reaction system at various gas flow rates and the combination of on-mass and mass-shift modes was evaluated. Cadmium, $\mathrm{Cr}$, $\mathrm{Ni}$, and $\mathrm{Pb}$ were determined as free atomic ions while As and $\mathrm{V}$ were determined as the oxides $\mathrm{AsO}^{+}$and $\mathrm{VO}^{+}$in the same run. Samples were prepared by microwave-assisted digestion with dilute nitric acid and hydrogen peroxide. Two plant-certified reference materials (apple leaves and tomato leaves) were used to check the accuracy. For tandem mass spectrometry with $0.5 \mathrm{~mL} \min ^{-1} \mathrm{O}_{2}$, recoveries in the $85-113 \%$ were typically obtained and no statistical differences were observed at the $95 \%$ confidence level ( $t$-test) in comparison with the certified values. Using these conditions, the limits of detection for the method were $0.01,0.0002,0.008,0.008,0.003$, and $0.002 \mu \mathrm{g} \mathrm{g}^{-1}$ for $\mathrm{As}, \mathrm{Cd}, \mathrm{Cr}, \mathrm{Ni}, \mathrm{Pb}$, and $\mathrm{V}$, respectively. The procedure was used for the analysis of four phytotherapic drugs and the determined concentrations were up to $0.168 \mu \mathrm{g} \mathrm{g}^{-1} \mathrm{As}, 0.03 \mu \mathrm{g} \mathrm{g}^{-1}$ $\mathrm{Cd}, 0.82 \mu \mathrm{g} \mathrm{g}^{-1} \mathrm{Cr}, 1.18 \mu \mathrm{g} \mathrm{g}^{-1} \mathrm{Ni}, 0.52 \mu \mathrm{g} \mathrm{g}{ }^{-1} \mathrm{~Pb}$, and $2.4 \mu \mathrm{g} \mathrm{g}^{-1} \mathrm{~V}$ with average precision values of $8 \%$ as the relative standard deviation. The found concentrations were compared with limits proposed in official guidelines and, in most cases, the values were below the maximum limits allowed.
\end{abstract}

\section{ARTICLE HISTORY}

Received 29 February 2016

Accepted 26 May 2016

\section{KEYWORDS}

Contaminants, elemental impurity determination ICP-MS/MS; inductively coupled plasma-tandem mass spectrometry; phytotherapy medicines; spectral interferences; trace analysis

\section{Introduction}

Medicinal plants are widely used as an alternative for treatment of diseases due to their therapeutic, prophylactic, and palliative properties. Besides the traditional forms of administration, these plants and their extracts may also be used as active ingredients in pharmaceutical preparations (Duke 1993). In addition to the therapeutic substances, phytomedicines may contain elemental impurities which are often present in trace levels and may be toxic or lead to product deterioration (Wang et al. 2000).

The main sources of elemental impurities in these drug formulations may be related to metal accumulation in plants (Barthwal, Nair, and Poonam 2008) and contamination of the 
raw materials or final product during manufacturing, packaging, and storage (Støving et al. 2013; Rudovica, Viksna, and Actins 2014). Similarly to all medicines, phytotherapy drugs should have a standardized composition and provide assurance on quality control and safety matters. Recently, the United States Pharmacopeia (USP) released two new chapters $<232>$ and $<233>$ (The United States Pharmacopeia 2015a, 2015b), concerning elemental impurity limits for 15 elements and recommended procedures based on inductively coupled plasma (ICP) techniques, but the implementation was postponed and it is intended to be established in early 2018 (The United States Pharmacopeia 2015c). The literature has also described procedures for determination of elemental impurities in pharmaceuticals by inductively coupled plasma optical emission spectrometry (ICP OES) and inductively coupled plasma mass spectrometry (ICP-MS) based on the USP chapter protocols (Van Hoecke, Catry, and Vanhaecke 2012; Støving et al. 2013; Fischer et al. 2014).

Among the analytical methods used for trace element analysis of herbal medicines (Yuan, Chapman, and Wu 2011), ICP-MS is attractive due to suitable sensitivity, multielemental characteristics, and high sample throughput (Thomas 2013); however, mass analyzers based on quadrupole spectrometers present low resolution (ca. $1 \mathrm{amu}$ ) and are prone to severe spectral interferences due to polyatomic species and isobaric overlaps. Over the years, several strategies have been used to overcome interferences in quadrupole ICPMS, including mathematical correction equations, cool plasma technology, and the use of collision/reaction cells (Thomas 2013). In addition, the use of sector field mass spectrometers (SF ICP-MS) with high resolution is a straightforward approach to overcome spectral overlaps; however, this technique is expensive and the limits of detection may be deteriorated due to lower ion transmission when the required resolution is increased.

Recently, ICP tandem mass spectrometry (ICP-MS/MS) was proposed for inorganic analysis, presenting a novel technology to overcome spectral overlaps. The instrument presents an additional quadrupole (quadrupole 1) located before the octopole reaction system $\left(\mathrm{ORS}^{3}\right)$, which acts as a mass filter and allows only the target mass to reach the collision/ reaction cell. After the cell, the second quadrupole (quadrupole 2) operates as a conventional mass analyzer. Such configuration provides better efficiency and selectivity in collision/reaction processes for the correction of spectral interferences.

The instrument is versatile and may be operated in the on-mass or mass-shift modes (Balcaen et al. 2015). In the on-mass mode, both quadrupoles select the same target mass of the ions entering and leaving the $\mathrm{ORS}^{3}$ (quadrupole $1=$ quadrupole 2). In the mass-shift mode, the precursor ions entering the cell are set in the first quadrupole for a target mass, while the second quadrupole selects the reaction product in specific $m / z$, which is the analyte's $\mathrm{m} / z$ and the mass of the reaction gas used (e.g., quadrupole $2=$ quadrupole $1+16$, in case of oxygen; or quadrupole $2=$ quadrupole $1+17$, in case of ammonia) (Sugiyama and Nakano 2014). The use of mass-shift mode with oxygen (Balcaen et al. 2013; Amais et al. 2014; Balcaen et al. 2014; Amais et al. 2015; Amaral et al. 2015; Jackson, Liba, and Nelson 2015; Virgilio et al. 2015), ammonia (Balcaen et al. 2014), and methyl fluoride (Bolea-Fernandez et al. 2014; Bolea-Fernandez et al. 2015) as the reaction gas for ICP-MS/MS has been reported in the literature. However, the combination of on-mass and mass-shift modes for elements with different reactivities in the same run is an underexplored strategy and requires thorough studies concerning the feasibility and possible effects over the sensitivity and accuracy of methods. Moreover, considering recent 
legislation for pharmaceutical analysis, the development of sensitive methods based on microwave-assisted digestion and plasma-based techniques are of utmost importance.

In this work, we evaluate the performance of ICP tandem mass spectrometry (ICP-MS/ MS) for the determination of $\mathrm{As}, \mathrm{Cd}, \mathrm{Cr}, \mathrm{Ni}, \mathrm{Pb}$, and $\mathrm{V}$ in phytotherapy medicines. Oxygen was used as a reaction gas into the $\mathrm{ORS}^{3}$ at different gas flow rates, and the influence of the on-mass and mass-shift modes on sensitivity, accuracy, and precision was studied.

\section{Experimental}

\section{Instrumentation}

All measurements were performed with an Agilent 8800 ICP-MS (Agilent Technologies, Japan) equipped with two quadrupole mass analyzers (quadrupole 1 and quadrupole 2), located in between the $\mathrm{ORS}^{3}$ as a collision/reaction cell. Pure oxygen ( $\geq 99.999 \%$, Air Products, São Paulo, SP, Brazil) was used as a reaction gas to generate the oxide species of the analytes. The ICP-MS/MS operational parameters are shown in Table 1. Sample preparation was performed using an Ethos 1600 microwave oven (Milestone, Sorisole, Italy).

\section{Reagents and standard solutions}

Ultrapure water (resistivity $>18.2 \mathrm{M} \Omega \mathrm{cm}$ ) and nitric acid (Merck, Darmstadt, Germany) obtained from a sub-boiling distillation system (Milestone) were used to prepare all analytical solutions. Standard solutions were prepared by adequate dilution of $1000 \mathrm{mg} \mathrm{L}^{-1}$ As, $\mathrm{Cd}, \mathrm{Cr}, \mathrm{Ni}, \mathrm{Pb}$, and V stock solutions (Fluka Analytical, St. Gallen, Switzerland) in $1 \% \mathrm{v} \mathrm{v}^{-1} \mathrm{HNO}_{3}$.

\section{Microwave-assisted digestion}

Two plant-certified reference materials (CRMs), apple leaves (NIST SRM 1515) and tomato leaves, (NIST SRM 1573a) from the National Institute of Standard and Technology (NIST,

Table 1. Operational conditions for ICP-MS/MS.

\begin{tabular}{|c|c|c|}
\hline Instrument parameter & \multicolumn{2}{|c|}{ Operating condition } \\
\hline Radiofrequency power (kW) & \multicolumn{2}{|c|}{1.55} \\
\hline Sampling depth (mm) & \multicolumn{2}{|c|}{8.0} \\
\hline Nebulizer & \multicolumn{2}{|c|}{ Concentric nebulizer-glass } \\
\hline Spray chamber & \multicolumn{2}{|c|}{ Scott type-double pass } \\
\hline Plasma gas flow rate $(\mathrm{L} \mathrm{min}-1)$ & \multicolumn{2}{|c|}{18} \\
\hline Auxiliary gas flow rate $\left(\mathrm{L} \mathrm{min}^{-1}\right)$ & \multicolumn{2}{|c|}{1.8} \\
\hline Carrier gas flow rate $\left(\mathrm{L} \mathrm{min}^{-1}\right)$ & \multicolumn{2}{|c|}{1.09} \\
\hline Integration time (s) & \multicolumn{2}{|c|}{3.0} \\
\hline Mass/charge ratios selected in Q1 & \multicolumn{2}{|c|}{$51(\mathrm{~V}) ; 52(\mathrm{Cr}) ; 60(\mathrm{Ni}) ; 75(\mathrm{As}) ; 112(\mathrm{Cd}) ; 208(\mathrm{~Pb})$} \\
\hline Operating mode & Single quadrupole & MS/MS \\
\hline Cell gas & No gas & 02 \\
\hline Gas flow rate $\left(\mathrm{mL} \mathrm{min}^{-1}\right)$ & 0 & 0.50 and 0.75 \\
\hline \multirow[t]{7}{*}{ Mass/charge ratios monitored in Q2 } & On-mass mode & Mass-shift mode \\
\hline & $51(\mathrm{~V})$ & 51 (V); 67 (VO) \\
\hline & $52(\mathrm{Cr})$ & $52(\mathrm{Cr}) ; 68(\mathrm{CrO})$ \\
\hline & 60 (Ni) & $60(\mathrm{Ni}) ; 76(\mathrm{NiO})$ \\
\hline & 75 (As) & 75 (As); 91 (AsO) \\
\hline & $112(\mathrm{Cd})$ & $112(\mathrm{Cd}) ; 128(\mathrm{CdO})$ \\
\hline & $208(\mathrm{~Pb})$ & $208(\mathrm{~Pb}) ; 224(\mathrm{PbO})$ \\
\hline
\end{tabular}

ICP-MS/MS, inductively coupled plasma-tandem mass spectrometry. 
Gaithersburg, MD, USA) were used to check the accuracy. Four phytotherapy drugs with labeled concentrations per capsule of $200 \mathrm{mg}$ Boldo (Peumus boldus), $300 \mathrm{mg}$ Ginseng (Panax ginseng), $250 \mathrm{mg}$ Green Tea (Camellia sinensis), and $100 \mathrm{mg}$ Kava-kava (Piper methysticum) were purchased at a local pharmacy in São Carlos (SP, Brazil).

For sample digestion, masses of approximately $300 \mathrm{mg}$ were accurately weighed directly in the Teflon-PFA digestion vessels, followed by the addition of $3 \mathrm{~mL}$ of concentrated $\mathrm{HNO}_{3}\left(16 \mathrm{~mol} \mathrm{~L}^{-1}\right), 3 \mathrm{~mL}$ of distilled and deionized water, and $2 \mathrm{~mL}$ of $30 \% \mathrm{~m} \mathrm{~m}^{-1}$ $\mathrm{H}_{2} \mathrm{O}_{2}$. The microwave-assisted digestions for CRMs and samples were performed using a two-step heating program, consisting of a $10 \mathrm{~min}$ ramp to $200^{\circ} \mathrm{C}$ followed by a $10 \mathrm{~min}$ hold at $200^{\circ} \mathrm{C}$. After cooling down to room temperature, the samples were diluted to $50.0 \mathrm{~mL}$ with distilled and deionized water. The digestions were made in triplicate.

\section{Results and discussion}

\section{Analytical performance}

The occurrence and extension of the reactions in reaction cells are intimately related to the physical-chemical properties of the analytes and cell gas used. The efficiency of oxygen reactions into the $\mathrm{ORS}^{3}$ is also dependent upon the gas flow rate. In mass-shift mode, the reaction of analyte ions from plasma with the oxygen usually occurs through the transfer of oxygen atoms, resulting in an oxide-based ion with $m / z$ dislocated by 16 atomic mass units from the original analyte's $m / z$. For some reactive elements such as As and P, the activation energy required for ionic reactions in gas phase is negligible, so exothermic $\left(\Delta H_{\mathrm{r}}<0\right)$ and spontaneous reactions take place. Hence, the oxides of the elements are the major products. For less reactive elements such as $\mathrm{Cu}$ and $\mathrm{Pb}$, the monitoring of oxide ions is not recommended due to energetically unfavorable reactions $\left(\Delta H_{r}>0\right)$ or the occurrence of charge transfer reactions with oxygen, which results in neutral species of the analyte (Agilent Technologies 2015). Therefore, the on-mass mode is more useful for these elements. In addition, the use of oxygen into the cell may also promote reactions with polyatomic species, and the use of on-mass mode may lead to interference-free determinations (Amais et al. 2015).

Considering the distinct reactivity of the elements with $\mathrm{O}_{2}$, the analytical performance of an ICP-MS/MS operating in both single quadrupole mode in absence of cell gas and MS/MS mode with $\mathrm{O}_{2}$ into the $\mathrm{ORS}^{3}$ under different gas flow rates $(0.50$ and $0.75 \mathrm{~mL}$ $\min ^{-1} \mathrm{O}_{2}$ ) was evaluated for $\mathrm{As}, \mathrm{Cd}, \mathrm{Cr}, \mathrm{Ni}, \mathrm{Pb}$, and $\mathrm{V}$. In each case, linear analytical curves $\left(r^{2}>0.99\right)$ in $0.1-100 \mu \mathrm{g} \mathrm{L}{ }^{-1}$ were obtained for the evaluation of figures of merit. Results for sensitivity, as the slope of analytical curves, and limits of detection and quantification, as 3 or 10 times the standard deviation of blank $(n=12)$ divided by the slope, respectively, were obtained for on-mass (quadrupole $1=$ quadrupole 2) and mass-shift (quadrupole $2=$ quadrupole $1+16$ ) modes. The results are shown in Table 2.

In general, sensitivities decreased when $\mathrm{O}_{2}$ was used and also when the gas flow rate is increased. In MS/MS mode, As and $\mathrm{V}$ presented better sensitivities and lower limits of detection when mass-shift mode was used, and the oxides $\left({ }^{75} \mathrm{As}^{16} \mathrm{O}^{+}\right.$and $\left.{ }^{51} \mathrm{~V}^{16} \mathrm{O}^{+}\right)$were monitored in comparison with the on-mass mode $\left({ }^{75} \mathrm{As}^{+}\right.$and $\left.{ }^{51} \mathrm{~V}^{+}\right)$. On the other hand, the sensitivity and limits of detection were improved for $\mathrm{Cd}, \mathrm{Cr}, \mathrm{Ni}$, and $\mathrm{Pb}$ when the same target masses were selected in both quadrupoles (on-mass mode). According to the 


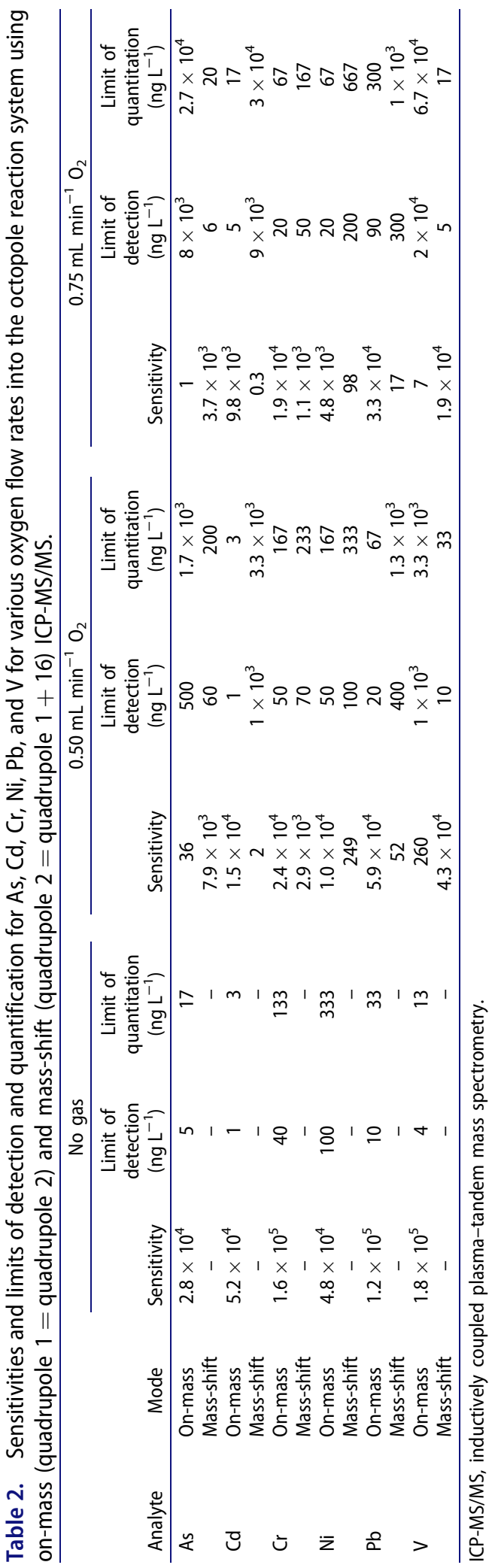


literature (Agilent Technologies 2015), the reactions of As and V with oxygen are thermodynamically favorable $\left(\Delta H_{\mathrm{r}}=-0.63 \mathrm{eV}\right.$ for As and $-0.85 \mathrm{eV}$ for $\left.\mathrm{V}\right)$ while for $\mathrm{Cd}$, $\mathrm{Cr}, \mathrm{Ni}$, and $\mathrm{Pb}$, endothermic and less favorable reactions with $\mathrm{O}_{2}$ are generally observed $\left(\Delta H_{\mathrm{r}}=+1.38 \mathrm{eV},+2.36 \mathrm{eV},+2.9 \mathrm{eV}\right.$ for $\mathrm{Cr}, \mathrm{Ni}$, and $\mathrm{Pb}$, respectively).

It was demonstrated by Sugiyama and Nakano (2014) that when the ORS ${ }^{3}$ was pressurized with $\mathrm{O}_{2}$, the prevalent forms for the evaluated analytes were ${ }^{75} \mathrm{As}^{16} \mathrm{O}^{+,}{ }^{112} \mathrm{Cd}^{+,}{ }^{52} \mathrm{Cr}^{+}$, ${ }^{60} \mathrm{Ni}^{+},{ }^{208} \mathrm{~Pb}^{+}$, and ${ }^{51} \mathrm{~V}^{16} \mathrm{O}^{+}$. In these cases, the lowest limits were obtained for $\mathrm{Cd}$ $\left(1 \mathrm{ng} \mathrm{L}^{-1}\right)$ and $\mathrm{Pb}\left(20 \mathrm{ng} \mathrm{L}^{-1}\right)$ at $0.5 \mathrm{~mL} \mathrm{~min}^{-1}$ and for As $\left(6 \mathrm{ng} \mathrm{L}^{-1}\right), \mathrm{Cr}\left(20 \mathrm{ng} \mathrm{L}^{-1}\right)$, Ni $\left(20 \mathrm{ng} \mathrm{L}^{-1}\right)$, and $\mathrm{V}\left(5 \mathrm{ng} \mathrm{L}^{-1}\right)$ at $0.75 \mathrm{~mL} \mathrm{~min}^{-1} \mathrm{O}_{2}$. It is important to consider that despite sensitivity losses caused by the use of $\mathrm{O}_{2}$ into the cell, background signals and the standard deviation for the blank were also significantly lower. Thus the limits of detection were generally better or similar to those obtained in single quadrupole mode. In spite of the possibility of the instrument operation using $\mathrm{O}_{2}$ into the $\mathrm{ORS}^{3}$ for single quadrupole mode, the reaction processes presented low selectivity and may lead to inaccurate results, and hence this strategy was not evaluated in this work.

\section{Accuracy and practical analysis}

The accuracy of procedures using on-mass and mass-shift modes for different oxygen flow rates was checked by analysis of two plant-CRMs. Recoveries for NIST SRM 1515 apple leaves and NIST SRM 1573a tomato leaves are shown in Tables 3 and 4, respectively. In the single mode, the appropriate recoveries were only obtained for $\mathrm{Cd}$ and $\mathrm{Pb}$ in NIST SRM 1515 apple leaves and Ni in NIST SRM 1573a tomato leaves. For the MS/MS mode, the use of $\mathrm{O}_{2}$ as reaction gas combined with mass-shift mode for As and $\mathrm{V}\left(\mathrm{AsO}^{+}\right.$and $\left.\mathrm{VO}^{+}\right)$and on-mass mode for $\mathrm{Cd}, \mathrm{Cr}, \mathrm{Ni}$, and $\mathrm{Pb}\left(\mathrm{Cd}^{+}, \mathrm{Cr}^{+}, \mathrm{Ni}^{+}\right.$, and $\left.\mathrm{Pb}^{+}\right)$provided recoveries of $85-113 \%$ for $0.5 \mathrm{~mL} \mathrm{m^{-1 }} \mathrm{O}_{2}$ and $68-112 \%$ for $0.75 \mathrm{~mL} \mathrm{~min}^{-1}$ in both CRMs.

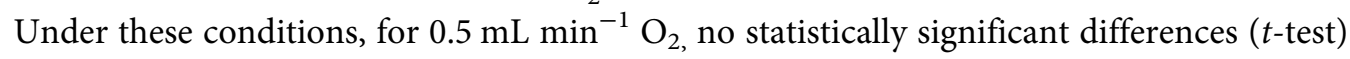
were observed at $95 \%$ confidence level, and the calculated $t$ values were lower than 4.3 (Tables 3 and 4). However, for $0.75 \mathrm{~mL} \mathrm{~min}^{-1} \mathrm{O}_{2}$, the determined concentrations for $\mathrm{V}$ in NIST SRM 1515 apple leaves and of Cd, Cr, and V in NIST SRM 1573a tomato leaves were not in agreement with the certified values at the same confidence level, and $t$ values were up to 33.8 .

It is worth noting that when $\mathrm{O}_{2}$ was used in mass-shift mode for elements with lower reactivity, inaccurate results (e.g., Ni recoveries up to 173\%) or inadequate sensitivity (as for $\mathrm{Cd}$ in the apple leaves) were generally obtained and the determined values were statistically distinct. The same effect is observed for more reactive elements monitored in on-mass mode, where low sensitivities impaired the determination of As and V. The combination of both on-mass and mass-shift modes for different elements in the same run is an interesting strategy for sensitive and accurate analysis by ICP-MS/MS. Average precision values, as the relative standard deviation, were lower for the MS/MS mode (8\%) in comparison with single quadrupole mode $(11 \%)$. Furthermore, the average precision for all analytes in mass-shift mode (7.5\%) was lower than for the on-mass mode $(9.1 \%)$.

Considering sensitivities, limits of detection, quantification, and accuracy, the procedure using $0.5 \mathrm{~mL}$ min ${ }^{-1} \mathrm{O}_{2}$ and monitoring of ${ }^{75} \mathrm{As}^{16} \mathrm{O}^{+},{ }^{112} \mathrm{Cd}^{+},{ }^{52} \mathrm{Cr}^{+},{ }^{60} \mathrm{Ni}^{+},{ }^{208} \mathrm{~Pb}^{+}$, and ${ }^{51} \mathrm{~V}^{16} \mathrm{O}^{+}$species was used for the analysis of phytotherapic drugs (Table 5). Concentrations ranging $<0.01-0.168 \mu \mathrm{g} \mathrm{g}^{-1} \mathrm{As},<0.0002-0.03 \mu \mathrm{g} \mathrm{g}^{-1} \mathrm{Cd}, 0.27-0.82 \mu \mathrm{g} \mathrm{g}^{-1} \mathrm{Cr}, 0.25-1.18 \mu \mathrm{g} \mathrm{g}^{-1} \mathrm{Ni}$, 


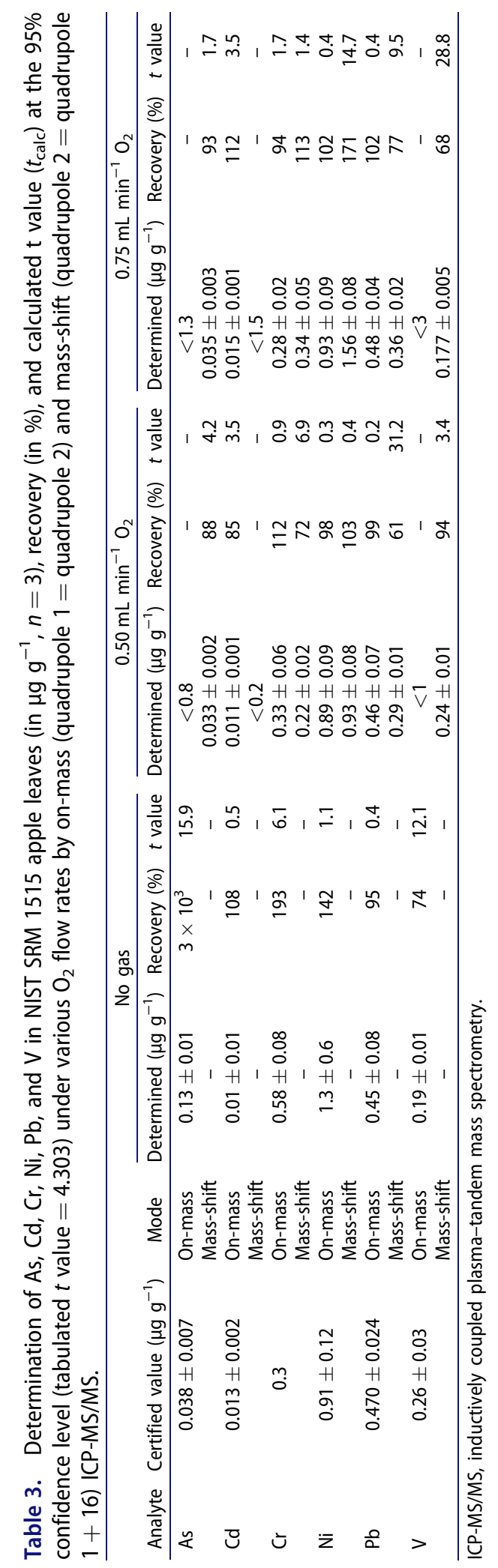




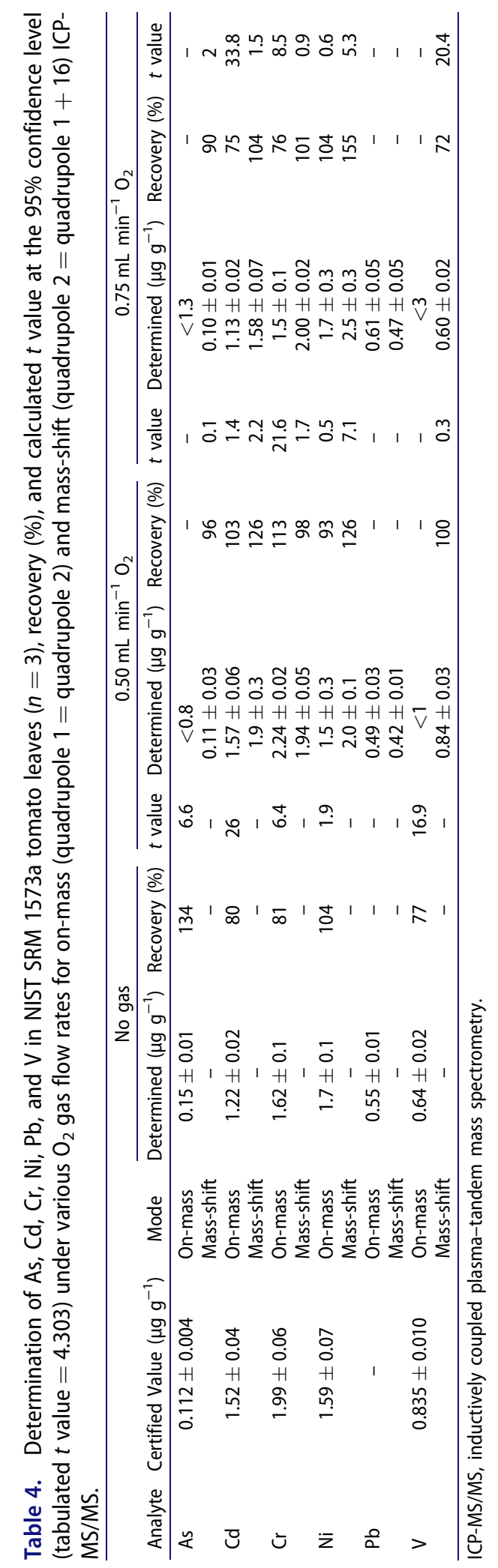


Table 5. Determination of $\mathrm{As}, \mathrm{Cd}, \mathrm{Cr}, \mathrm{Ni}, \mathrm{Pb}$, and $\mathrm{V}$ in phytotherapic drugs by ICP-MS/MS $(n=3)$.

\begin{tabular}{lcccccc}
\hline Sample & $\mathrm{As}\left(\mu \mathrm{g} \mathrm{g}^{-1}\right)$ & $\mathrm{Cd}\left(\mu \mathrm{g} \mathrm{g}^{-1}\right)$ & $\mathrm{Cr}\left(\mu \mathrm{g} \mathrm{g}^{-1}\right)$ & $\mathrm{Ni}\left(\mu \mathrm{g} \mathrm{g}^{-1}\right)$ & $\mathrm{Pb}\left(\mu \mathrm{g} \mathrm{g}^{-1}\right)$ & $\left.\mathrm{V}(\mu \mathrm{g} \mathrm{g})^{-1}\right)$ \\
\hline Green tea & $<0.01$ & $0.023 \pm 0.001$ & $0.48 \pm 0.04$ & $1.18 \pm 0.03$ & $0.52 \pm 0.02$ & $0.19 \pm 0.05$ \\
Boldo & $0.168 \pm 0.004$ & $0.006 \pm 0.001$ & $0.82 \pm 0.04$ & $0.87 \pm 0.06$ & $0.40 \pm 0.04$ & $2.4 \pm 0.2$ \\
Kava-kava & $<0.01$ & $<0.0002$ & $0.27 \pm 0.02$ & $0.25 \pm 0.01$ & $<0.003$ & $0.026 \pm 0.001$ \\
Ginseng & $<0.01$ & $0.03 \pm 0.01$ & $0.43 \pm 0.03$ & $0.50 \pm 0.03$ & $0.22 \pm 0.08$ & $0.92 \pm 0.05$ \\
Limit of detection & 0.01 & 0.0002 & 0.008 & 0.008 & 0.003 & 0.002 \\
$\quad$ International Conference on & 1.5 & 0.5 & 1100 & 20 & 0.5 & 10 \\
$\quad$ Harmonization limits & & & & & & 10 \\
$\quad$ The United States & 0.15 & 2.5 & - & 50 & 0.5 & 10 \\
$\quad$ Pharmacopeia limits & & & & & & \\
\hline
\end{tabular}

$<0.003-0.52 \mu \mathrm{g} \mathrm{g}^{-1} \mathrm{~Pb}$, and 0.026-2.4 $\mu \mathrm{g} \mathrm{g}^{-1} \mathrm{~V}$ were found in Boldo $200 \mathrm{mg}$, Ginseng $300 \mathrm{mg}$, Green Tea $250 \mathrm{mg}$, and Kava-kava $100 \mathrm{mg}$ medication. According to the International Conference on Harmonisation of Technical Requirements for Registration of Pharmaceuticals for Human Use and The USP guidelines, the impurity concentrations were below the maximum limits allowed in most cases, except for the samples Boldo (for As) and green tea (for $\mathrm{Pb}$ ), which presented values slightly higher than the established limits. (International Conference on Harmonisation of Technical Requirements for Registration of Pharmaceuticals for Human Use 2016; The United States Pharmacopeia 2015a). In all cases, the limits of detection of this procedure were sufficiently lower compared to values specified in the legislation.

Higher concentrations of toxic metals such as As $\left(<0.005-3.77 \mu \mathrm{g} \mathrm{g}^{-1}\right), \mathrm{Cd}(<0.01-$ $\left.0.368 \mu \mathrm{g} \mathrm{g}^{-1}\right)$, and $\mathrm{Pb}\left(<0.02-48.6 \mu \mathrm{g} \mathrm{g}^{-1}\right)$ were described in the literature, but still within the range found in the this work (Dolan et al. 2003). In another paper, 19 elements were determined in three types of herbal products from different Asian countries by ICP-MS (Nookabkaew, Rangkadilok, and Satayavivad 2006). The determined concentrations of As (0.01-0.75 $\left.\mu \mathrm{g} \mathrm{g}{ }^{-1}\right)$, Cd (0.001-4.77 $\left.\mu \mathrm{g} \mathrm{g}^{-1}\right), \mathrm{Cr}\left(0.205-12.42 \mu \mathrm{g} \mathrm{g} \mathrm{g}^{-1}\right), \mathrm{Ni}$ $\left(0.368-9.19 \mu \mathrm{g} \mathrm{g}^{-1}\right), \mathrm{Pb}\left(0.06-64.4 \mu \mathrm{g} \mathrm{g}^{-1}\right)$, and $\mathrm{V}\left(0.06-7.72 \mu \mathrm{g} \mathrm{g}^{-1}\right)$ were in a wide range and are consistent with the values obtained in the present work.

\section{Conclusion}

The use of tandem mass spectrometry with oxygen into the $\mathrm{ORS}^{3}$ and the combination of on-mass and mass-shift modes for different analytes was demonstrated as efficient strategies to correct for spectral overlaps and provide accurate determinations. Due to its high sensitivity and compliance with the most recent international legislations, the reported procedure may be considered adequate for the determination of inorganic impurities in phytotherapic drugs and pharmaceutical preparations.

\section{Acknowledgments}

We thank Agilent Technologies for the technical support.

\section{Funding}

The authors would like to thank grants 2014/18393-1 and 2013/26857-5, São Paulo Research Foundation (FAPESP). J.A.N. and J.A.G.N are thankful to the Conselho Nacional de Desenvolvimento Científico e Tecnológico CNPq, Grants Nos. 303107/2013-8 and 443771/2014-6. 


\section{References}

Agilent Technologies. 2015. Agilent 8800 Triple Quadrupole ICP-MS: Understanding oxygen reaction mode in ICP-MS/MS. http://www.agilent.com/cs/library/technicaloverviews/public/ 5991-1708EN_TechOverview_ICP-MS_8800_ORS_mode.pdf (accessed May 6, 2016).

Amais, R. S., C. D. B. Amaral, L. L. Fialho, D. Schiavo, and J. A. Nóbrega. 2014. Determination of P, $\mathrm{S}$ and $\mathrm{Si}$ in biodiesel, diesel and lubricating oil using ICP-MS/MS. Analytical Methods 6:4516-20. doi:10.1039/c4ay00279b

Amais, R. S., A. Virgilio, D. Schiavo, and J. A. Nóbrega. 2015. Tandem mass spectrometry (ICP-MS/ MS) for overcoming molybdenum oxide interferences on Cd determination in milk. Microchemical Journal 120:64-68. doi: 10.1016/j.microc.2015.01.008

Amaral, C. D. B., R. S. Amais, L. L. Fialho, D. Schiavo, T. Amorim, A. R. A. Nogueira, F. R. P. Rocha, and J. A. Nóbrega. 2015. A novel strategy to determine As, Cr, Hg and V in drinking water by ICP-MS/MS. Analytical Methods 7:1215-20. doi:10.1039/c4ay02811b

Balcaen, L., E. Bolea-Fernandez, M. Resano, and F. Vanhaecke. 2014. Accurate determination of ultra-trace levels of Ti in blood serum using ICP-MS/MS. Analytica Chimica Acta 809:1-8. doi: 10.1016/j.aca.2013.10.017

Balcaen, L., E. Bolea-Fernandez, M. Resano, and F. Vanhaecke. 2015. Inductively coupled plasma Tandem mass spectrometry (ICP-MS/MS): A powerful and universal tool for the interference-free determination of (ultra)trace elements - A tutorial review. Analytica Chimica Acta 894:7-19. doi:10.1016/j.aca.2015.08.053

Balcaen, L., G. Woods, M. Resano, and F. Vanhaecke. 2013. Accurate determination of S in organic matrices using isotope dilution ICP-MS/MS. Journal of Analytical Atomic Spectrometry 28:33-39. doi:10.1039/c2ja30265a

Barthwal, J., S. Nair, and K. Poonam. 2008. Heavy metal accumulation in medicinal plants collected from environmentally different sites. Biomedical and Environmental Sciences 21:319-24. doi:10.1016/s0895-3988(08)60049-5

Bolea-Fernandez, E., L. Balcaen, M. Resano, and F. Vanhaecke. 2014. Potential of methyl fluoride as a universal reaction gas to overcome spectral interference in the determination of ultratrace concentrations of metals in biofluids using inductively coupled plasma-tandem mass spectrometry. Analytical Chemistry 86:7969-77. doi:10.1021/ac502023h

Bolea-Fernandez, E., L. Balcaen, M. Resano, and F. Vanhaecke. 2015. Interference-free determination of ultra-trace concentrations of arsenic and selenium using methyl fluoride as a reaction gas in ICP-MS/MS. Analytical and Bioanalytical Chemistry 407:919-29. doi:10.1007/s00216-0148195-8

Dolan, S. P., D. A. Nortrup, P. M. Bolger, and S. G. Capar. 2003. Analysis of dietary supplements for arsenic, cadmium, mercury, and lead using inductively coupled plasma mass spectrometry. Journal of Agricultural and Food Chemistry 51:1307-12.

Duke, J. A. 1993. Medicinal plants and the pharmaceutical industry. In New crops, ed. J. Janick and J. E. Simons, 664-69. New York: J. Wiley and Sons.

Fischer, L., B. Zipfel, G. Koellensperger, J. Kovac, S. Bilz, A. Kunkel, C. Venzago, and S. Hann. 2014. Flow injection combined with ICP-MS for accurate high throughput analysis of elemental impurities in pharmaceutical products according to USP $<232>\mid<233>$. Journal of Pharmaceutical and Biomedical Analysis 94:121-29. doi:10.1016/j.jpba.2014.02.016

International Conference on Harmonisation of Technical Requirements for Registration of Pharmaceuticals for Human Use. 2016. Guideline for elemental impurities Q3D. https://www.ich.org/ fileadmin/Public_Web_Site/ICH_Products/Guidelines/Quality/Q3D/Q3D_Step_4.pdf (accessed May 6, 2016).

Jackson, B. P., A. Liba, and J. Nelson. 2015. Advantages of reaction cell ICP-MS on doubly charged interferences for arsenic and selenium analysis in foods. Journal of Analytical Atomic Spectrometry 30:1179-83. doi:10.1039/c4ja00310a

Nookabkaew, S., N. Rangkadilok, and J. Satayavivad. 2006. Determination of trace elements in herbal tea products and their infusions consumed in Thailand. Journal of Agricultural and Food Chemistry 54:6939-44. doi:10.1021/jf060571w 
Rudovica, V., A. Viksna, and A. Actins. 2014. Application of LA-ICP-MS as a rapid tool for analysis of elemental impurities in active pharmaceutical ingredients. Journal of Pharmaceutical and Biomedical Analysis 91:119-22. doi:10.1016/j.jpba.2013.12.025

Støving, C., H. Jensen, B. Gammelgaard, and S. Stürup. 2013. Development and validation of an ICP-OES method for quantitation of elemental impurities in tablets according to coming US pharmacopeia chapters. Journal of Pharmaceutical and Biomedical Analysis 84:209-14. doi:10.1016/j.jpba.2013.06.007

Sugiyama, N., and K. Nakano. 2014. Reaction data for 70 elements using $\mathrm{O}_{2}, \mathrm{NH}_{3}$ and $\mathrm{H}_{2}$ gases with the Agilent 8800 triple quadrupole ICP-MS. http://www.agilent.com/cs/library/technicaloverviews/public/5991-4585EN_TechNote8800_ICP-QQQ_reactiondata.pdf (accessed May 6, 2016).

The United States Pharmacopeia. 2015a. General chapter <232> elemental impurities - Limits. http:// www.usp.org/sites/default/files/usp_pdf/EN/USPNF/key-issues/c232.pdf (accessed December 16, 2015a).

The United States Pharmacopeia. 2015b. General chapter $<233>$ Elemental impurities - Procedures. http://www.usp.org/sites/default/files/usp_pdf/EN/USPNF/key-issues/233_ElementalImpurities Procedures.pdf (accessed December 16, 2015b).

The United States Pharmacopeia. 2015c. General notices section 5.60.30 elemental impurities in USP drug products and dietary supplements. http://www.usp.org/usp-nf/notices/general-notices-section56030-elemental-impurities-usp-drug-products-and-dietary-supplements (accessed December 16, 2015c).

Thomas, R. 2013. Practical guide to ICP-MS: A tutorial for beginners. New York: CRC Press.

Van Hoecke, K., C. Catry, and F. Vanhaecke. 2012. Optimization of sample preparation and a quadrupole ICP-MS measurement protocol for the determination of elemental impurities in pharmaceutical substances in compliance with USP guidelines. Journal of Analytical Atomic Spectrometry 27:1909-19. doi:10.1039/c2ja30128h

Virgilio, A., R. S. Amais, D. Schiavo, and J. A. Nóbrega. 2015. Dilute-and-shoot procedure for determination of $\mathrm{As}, \mathrm{Cr}, \mathrm{P}, \mathrm{Pb}, \mathrm{Si}$, and $\mathrm{V}$ in ethanol fuel by inductively coupled plasma tandem mass spectrometry. Energy \& Fuels 29:4339-44. doi:10.1021/acs.energyfuels.5b00434

Wang, T., J. Wu, R. Hartman, X. Jia, and R. S. Egan. 2000. A multi-element ICP-MS survey method as an alternative to the heavy metals limit test for pharmaceutical materials. Journal of Pharmaceutical and Biomedical Analysis 23:867-90. doi:10.1016/s0731-7085(00)00361-7

Yuan, X., R. L. Chapman, and Z. Wu. 2011. Analytical methods for heavy metals in herbal medicines. Phytochemical Analysis 22:189-98. doi:10.1002/pca.1287 